\title{
Hybrid beasts of the Nordic Bronze Age
}

\author{
Laura Ahlqvist and Helle Vandkilde (1) \\ Department of Archaeology and Heritage Studies, Aarhus University, Aarhus, Denmark
}

\begin{abstract}
During the Nordic Bronze Age (NBA), hybrid beasts contributed to cosmological and mythical narratives on the main media of metal and rock. These hybrids are composed of body parts from particular animals - including bull, bird, snake, horse and human - which entangle with particular objects or images. On metalwork, they appear especially on bronze razors but also on shields, bowls, combs, helmets and in the shape of figurines. Their main occurrence clusters in the later part of the NBA that is characterised by social change. Especially cremation as the total metamorphosis of the human body aligns with a nexus of analogues firmly linking interspecies composites with ideas of bodily fluidity and transformation. Overall, this may be understood as a way of perceiving, and potentially controlling, the world. NBA hybridising art does not indicate that the religion of the era is reducible to mere animism throughout, but society certainly retained and put to use properties of an animistic tradition. Supported by contextual data, the article proposes that the hybrids related to shared NBA myths and religious practices while also legitimising the privilege and leadership of the upper echelons of NBA societies.
\end{abstract}

\section{ARTICLE HISTORY}

Received 22 February 2018 Accepted 2 August 2018

\section{KEYWORDS}

Nordic Bronze Age (NBA); hybrid; cosmology; elite; animism

\section{Introduction}

Hybrids composed of different beings formed part of the Nordic Bronze Age (NBA), but have so far merely received sporadic treatment by the archaeological research and have in some cases barely been noticed (e.g. Müller 1921, p. 52, fig. 185). By contrast, Late Iron Age and Viking Period hybridising imagery has been investigated and interpreted in terms of mythical narratives, shamanistic shape-shifting and the religiosity of privileged social groups (notably Price 2002, Hedeager 2010, 2011, p. 59ff, Kristoffersen 2010).

The present contribution aims to clarify the phenomenon of hybrid appearances in the NBA with an emphasis on versions in bronze. Essentially, complex interspecies relationships incorporated animals, humans and objects in a highly selective manner, including the choice of media. A number of questions transpire: which creatures are selected to be combined into hybrids, where is this imagery presented and how should hybrids be understood within the societal context of the NBA? In dialogue with adequate theory, and drawing on later analogies and similar imagery, we propose that NBA hybrids, that is combinations of different animals (including humans) and objects merged together, materialised aspects of animistic beliefs intertwined with the strategic making of identities in the upper societal rung and with particular references to warriorhood.

\section{Previous research in Scandinavia}

Different hybrid creatures have been recognised briefly in especially earlier archaeological literature (e.g. Müller 1921, p. 32, p. 52, Brøndsted 1938, p. 28ff, Broholm 1953, p. 19, Glob 1962, 1969), however, the present article represents the first overview of the NBA hybrids, as well as a comprehensive interpretation of the phenomenon.

Various combinations of bulls, people, snakes and horses on various Bronze Age artefacts and rock carvings have been discussed in relation to myths and similar iconography from the Ancient Near East by Kristiansen \& Larsson (2005, p. $320 \mathrm{ff}$ ). Bull's horns are thought to have represented divine rulership referencing Bronze Age mythology, and horses are assumed to function

CONTACT Laura Ahlqvist lauraelisabethsvopahlqvist@gmail.com @ Department of Archaeology and Heritage Studies, Aarhus University, Moesgård Allé 20, Aarhus 8270, Denmark

(c) 2018 The Partnership of the Danish Journal of Archaeology 
as a medium linking the Pantheon of divinities with its human counterparts of leaders and chiefs (Kristiansen \& Larsson 2005, p. 320ff).

Kaul (1998a, p. 200ff, 1998b, p. 28, fig. 56, p. 146 , fig. 357,2004 , p. $242 \mathrm{ff}$ ) also employs a religious framework in his interpretation of the hybrid creatures on the Late NBA razors as elements of the great narrative of the sun's journey across the sky (see also Goldhahn 2005). Similarly, the small figurines from Grevensvænge and Fårdal (Figure 1-2) are considered miniature reproductions of religious leaders or 'practitioners of rituals', and the twin helmets from Viksø are also discussed as objects of ritual significance (Kaul 1998a, p. 16ff).

The Viksø helmets (Figure 1a) were recently reexamined from a combined social and religious perspective: they appear as implicitly hybrid, as they incorporate selected animal and material parts and highlight human eyes and brows (Vandkilde 2013, p. 167ff). Vandkilde suggests that the two helmet carriers were meant to internalise the plethora of animal features, the semidivine warrior twins and their ships, which have a strong bearing on the wider mythical world of the Late NBA with parallels, for example, in the Grevensvænge figurines. Thus, on the one hand, shamanistic or animistic shape-shifting could be involved. On the other hand, rituals revolving around the two well known warrior adventurers may, by the Late NBA, have incorporated aggrandising components reminiscent of Mediterranean post-Bronze Age hero cults, in which gigantic, semi-divine ancestors played a profound role

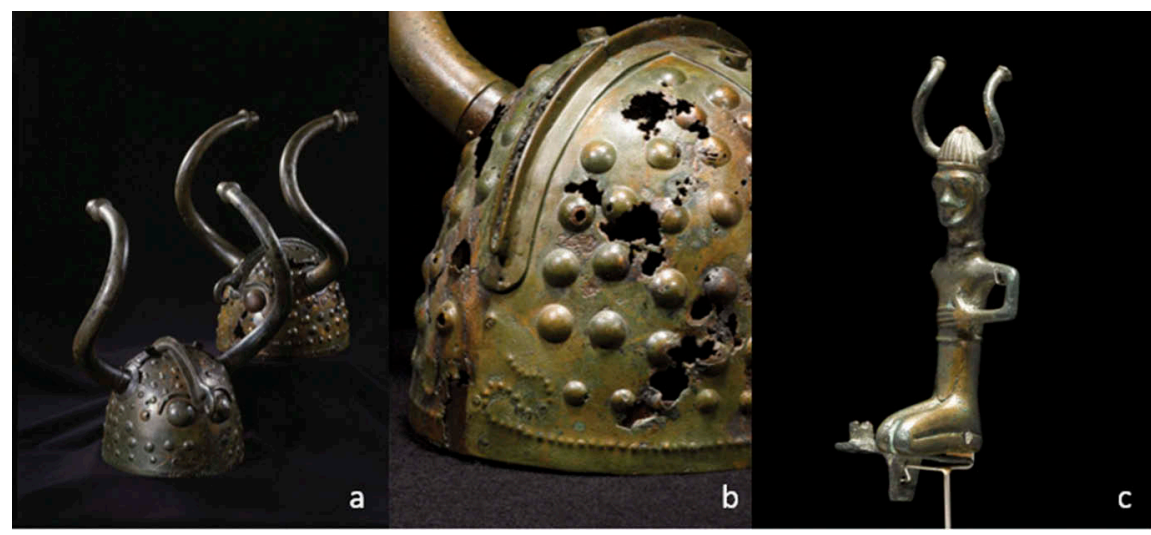

Figure 1. a: Twin bull-horned helmets from Viksø, northeast Zealand (Courtesy of the National Museum of Denmark, photo: Lennart Larsen) and b: a close-up (Courtesy of the National Museum of Denmark, photo: Roberto Fortuna \& Kira Ursem) of the swan-headed devices on stern and rear of the encircling longships. NBA IV. The imagery is hybridising on several levels while repeated on the Fogdarp yokes. c: Figurines of bull-horned twins from Grevensvænge, southeast Zealand (Courtesy of the National Museum of Denmark, photo: Roberto Fortuna \& Kira Ursem) which might, in conjunction with several rock carvings, suggest hybrids between bull and man or that certain males wore bull-horned helmets on particular occasions such as war - likely the same issue.

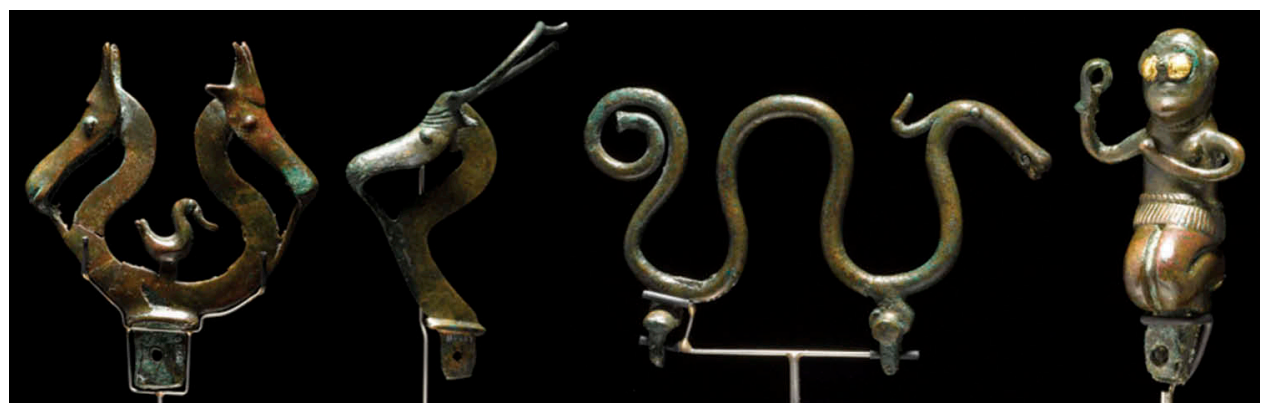

Figure 2. Figurines from Fårdal, central Jutland (NBA VI). Four horse heads, each crowned with bull's horns, were probably attached to stern and rear of a longship model. The passengers were figures of a divine golden-eyed female and an animal hybrid merging the head of a bull-horned horse and the wriggling body of a snake (Courtesy of the National Museum of Denmark, photo: Roberto Fortuna \& Kira Ursem). 
(Vandkilde 2013, p. 171ff). In a similar vein, Vandkilde has explained the emergence of NBA elite weaponry and warriorhood c. 1600-1500 BCE in the light of reformed religious beliefs in a tripartite cosmos: this involved complex humananimal-object relationships but usually without distinct hybridisations at this early point (Vandkilde 2014).

Hybrid creatures from other periods of prehistory have been more widely explored and interpreted, which is in stark contrast to the literature on the NBA hybrids. Often, it is suggested that they refer to ritual specialists or shamans (e.g. Lindstrøm 2012, p. 156ff). Hybrids are especially prominent in Late Iron Age and Viking Age animal styles (Figure 3) (Kristoffersen 2010, p. 263ff). Furthermore, fragmented human and animal remains thought to represent religious practices are found in different contexts during these periods (Hedeager 2011, p. 68ff). The significant role
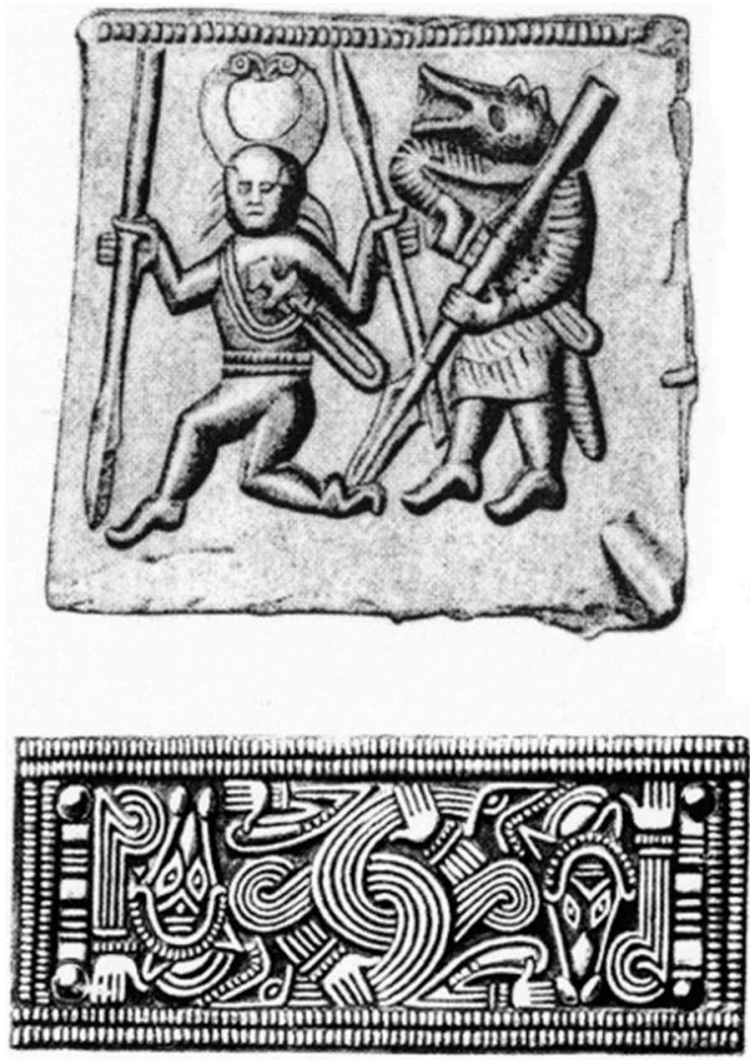

Figure 3. Hybrid animal art in the Nordic Late Iron Age and Viking Age often combine parts from different animals including humans. Examples: a: the Torslunda plate, Sweden, b: mounting from Söderby Karl, Sweden (a: drawing by Bengt Händel in Arbman 1980, p. 25, b: drawing by Harald Faith-Ell after Holmqvist 1951, Figure 7). of shape-shifting and shamanism as religionrelated practices was established with Price's early work (2001, 2002), and more recently, with Hedeager's comprehensive studies, they have become firmly linked to the hybrid realm of animal styles and the legitimisation of new forms of rulership. Drawing on later written sources about shape-shifting, Hedeager (2011, p. 75ff) perceives hybrids as the expression of a world where boundaries between different bodies - both human and animal - are not sharply drawn. She considers hybrid beings as shape-shifters who possess a fluid identity and body. Warriors, warfare, religion and power constitute entangled domains notably incorporating wolf, eagle and boar warriors (Hedeager 2010, p. 114ff, 2011, p. 75ff).

To use written and material sources as a direct basis for interpretations of iconography several centuries older may be a dubious endeavour. However, as a relational analogue (Wylie 1985), the contemporary interpretations of these earlier sources may work far better, especially because of the structural resemblance between NBA and Viking Age societies pointed out in recent years (e.g. Kristiansen 2016). Research in NBA hybrids is a new field and will benefit from the mentioned Iron Age studies.

\section{Interspecies entanglements in premodern human beliefs}

The NBA hybrid beings might be discussed in relation to various theoretical frameworks that concern transition, iconography and, above all, transformation. The most appropriate of theories to improve knowledge of the subject area are rooted in ethnographic examples from all over the world. Most notably, animism is relevant as metamorphosis between not only people and animals but also between different animals and between people and objects is a key element in societies with animistic traits (Ingold 2011, p. 123).

Animism, first described by Tylor (1871), or perhaps more appropriately, animistic notions should not be viewed as a religion with dogmas, but rather as a way of viewing the world, deeply embedded in everyday life and permeating through every sphere of society (Insoll 2011, p. 
1004f). Post-Tylor, animism has nevertheless often been conceptualised as the original form of religion, a research position which has been much debated (e.g. Stringer 1999), and in current research, there is a growing awareness of the changing nature of animism. Thus, animistic perceptions of the world may take different forms in different societies and are not solely tied to a hunter-gatherer way of life; in fact, they might combine with other belief traditions and cosmologies (e.g. Ingold 2011, p. 77ff). Rather than perceiving animism as the belief that people, animals and objects have similar souls, we might view it as the notion that a mighty force created and permeates the world and now inhabits all the creatures in it (Insoll 2011, p. 1004f, Peoples et al. 2016, p. 274f). This means that no shapes and bodies are stable but in constant flux, ever-changing and hybridising (Ingold 2011, p. 113). Communication with the spirits, animals and humans is essentially social and ensures the continued balance in the world as ritualised actions such as gift-giving/votive depositions, while permitting the giver to enter into a reciprocal relationship with nature and supernatural beings (Mauss 1990, p. 14ff, Jordan 2003, p. 137).

Animism is closely associated with shamanistic practices and its inherent idea of shape-shifting and hybrid existences between animals, humans and objects. Voluntary transformation in animistic societies is generally performed by the shaman, who leaves the human body and takes the shape of helping spirits to travel through different realms (Hultkrantz 1978, p. 12, Ingold 2011, p. 123). These helping spirits often have animal form and so the transformation can be achieved by wearing feathers or antlers as well as other animal parts (Hultkrantz 1978, p. 16, Niekum 2008, p. 157f). Interestingly, some NBA finds such as the Viksø helmets and potentially even the Hagendrup find do, in fact, seem to combine multiple parts of animals with human features whilst likely being worn by humans (Vandkilde 2013). Ethnographically the shaman's body is also known to merge with other bodies as he/she rides the animals, which move through air, water and on the ground, such as Odin's Sleipnir (Hultkrantz 1978, p. 16ff). In addition, the shaman has the power to transform completely into one of the helping animal spirits (Hultkrantz 1978, p 18), which would align more with the NBA solar myth (Kaul 1998a) and the sacred role of the NBA horse as a boundary crosser (Vandkilde 2014, Kveiborg 2017).

Alternatively, non-shamans might also achieve the power of transformation through the use of masks and costumes (Conneller 2004, 42ff), as the human physical appearance is altered, and the person appears animal. This phenomenon is known from several contemporary societies with animistic notions, for example in Siberia and Mongolia (Niekum 2008, p. 157f, Little et al. 2016, p. 2f). Masks should not be seen as a means of hiding the carrier's identity, but rather as a means of exposing the spirits and animals that live within the human bearer, in other words, the carrier's true identity and face. Some masks, in fact, have a hybrid identity themselves; a mask viewed from one angle could resemble an animal and, from another, a human (Ingold 2011, p. 123ff). The mask-like Viksø helmets carry all these qualities (Figure 1a).

Animistic beliefs may manifest themselves in art and iconography, which are used as physical manifestations depicting the dialogue between people, animals and objects (Ingold 2011, p. 121ff), as well as transformations or the mere possibility of transformation (Hedeager 2011, p. 66ff). Iconographic representation of transformation has also been known to illustrate myths and cosmology, for example the myth of Odin, master of disguise, who is associated with animals (two birds and two wolves) as well as objects (a spear and a ring). The possibility of existence beyond the body is also seen in animal style, where people and animals are interwoven (Hedeager 2011, p. 7ff) (Figure 3). This same animal style, which often has religious connotations, can also be linked to a range of non-religious myths and social identities, for example warriors and kings who turn into animals (Hedeager 2011, p. 84). This recalls the warriors entwined with features from bird and bull in NBA imagery.

\section{On the categorisation of NBA hybrids}

Figurative Bronze Age art is often abstract and stylised, which can complicate defining what is a 
hybrid and what is just stylisation. The distinction between hybrids and stylised animals and the potential challenges linked to this is worthy of a nuanced discussion, which is outside the scope of the present pilot. However, we argue that some creatures are simply too surreal to be considered animals with merely stylised or overaccentuated features. Furthermore, some of the hybrids discussed in the present article appear next to nonfantastical looking animals (see Figure 4c), thus solidifying the interpretation that these are, in fact, something other than animals.

Another grey zone concerns the many instances in which whole or partial animals combine with certain objects. Items incorporating a single animal include, for example, the horse-headed belthooks (Figure 5), numerous razors with horse, swan or snake-headed handle (Kaul 1998a, 1998b), the Trundholm sun chariot, and Late NBA bronze vessels displaying the sun-bird-ship motif (e.g. the vessel on Figure 6). Razors may themselves symbolise the vessel transporting the sun (Kaul 2004). If all these objects and images merging with parts from one animal - usually its head and often all together referencing the transport of the sun - are categorised as true hybrids, the phenomenon is very comprehensive. This is a possibility though, and it is interesting that such simple crossbreeds between object and animal appear in art already with the breakthrough of the NBA c. 1600 BCE and continue throughout the era, hence emphasising the significance of specific animals in specific NBA life worlds, which also embraced hybrids per se.
To keep the analysis concise, only creatures combining attributes from more than one animal (counting humans) are included below. This aligns with Hedeager's statement that hybridity concerns porous boundaries between different bodies both human and animal - and that this state of being characterises the art world as well as certain social practices (Hedeager 2010, p. 114ff, 2011, p. 75ff). The hybridising objects and images themselves with their source material (bronze, gold, rock, clay) can be considered primary contexts of importance for the interpretation, while it is without doubt significant that they often originate from extraordinary burials and votive deposits. As shown by Kaul (1998a, 2004) and others (e.g. Felding 2015), there is, furthermore, a level of consistency between scenery on rock and metalwork, which should be considered in the interpretive undertaking.

\section{The canon of hybrids on NBA metalwork}

Based on the above criteria, it appears that the hybrids follow a prescribed canon. Hybrid imagery pertains to razors in addition to notably shields, drinking vessels, combs and helmets, and in the shape of figurines. Alongside humans, the animals comprise horse, serpent, bird, bull, fish and a single dog. The entities of suns and water currents may be added. The preferred body parts comprise human face (including beard and accentuated eyes), bird of prey beak, bull's horns, horse head, serpent

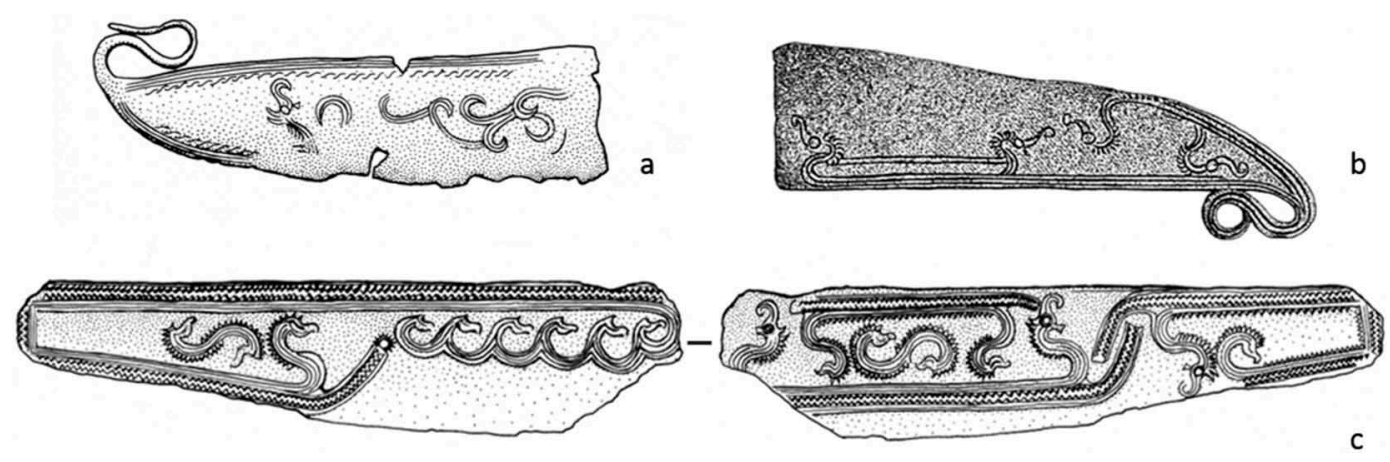

Figure 4. Repeated representations of the hybridised creature on Late NBA razors. Even though there are slight variations to the motif, the overall image appears the same, which is further underlined by the similarity in posture. The hybridised creature is clearly distinguishable from a horse on c, where it co-appears with more natural-looking horses without the oversized eye, the beard and the beak. (after Kaul 1998b: a: Figure 1, b: fig. 203, c: fig. 313). 

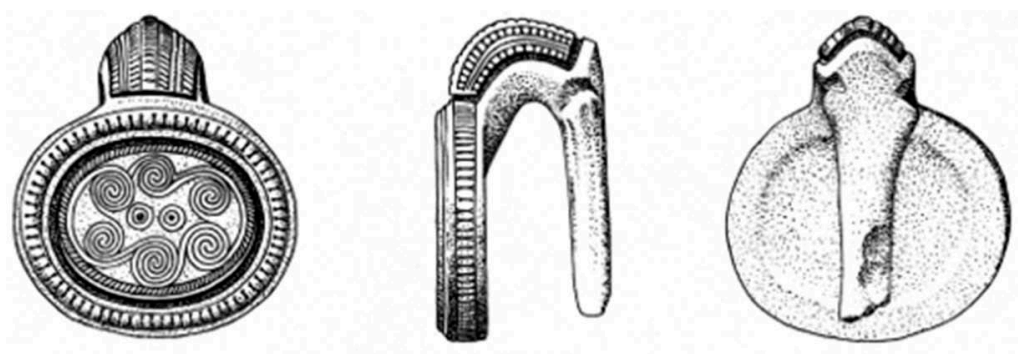

a
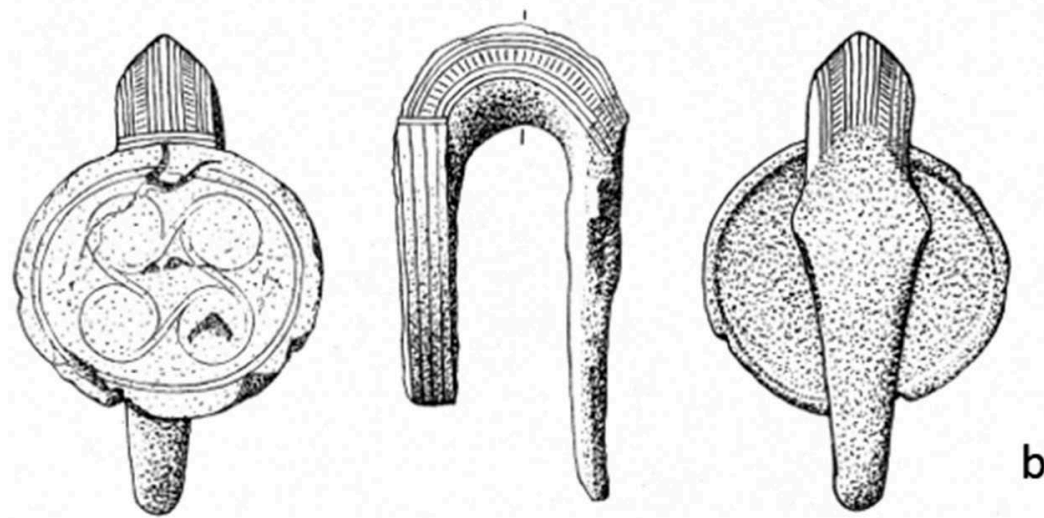

Figure 5. Examples of horse-headed belt hooks from Fredensborg and Copenhagen counties, Zealand (after Aner and Kersten 1973: a: Ke 364, b: $518 \mathrm{~N}$ ). The earliest have a straight arm that develops into a sun-disc pulled by the horse. The horse heads range from stylised to naturalistic. The belt hooks are not categorised as full interspecies hybrids here but relate to these: the horse's head entangles with material parts: firstly, the practical belt fastener and, secondly, the symbolic-religious reference to the sun horse. Belt hooks often occur in rich male burials below mounds. They date from NBA IB to NBA II early (c. 1600-1400 BCE).

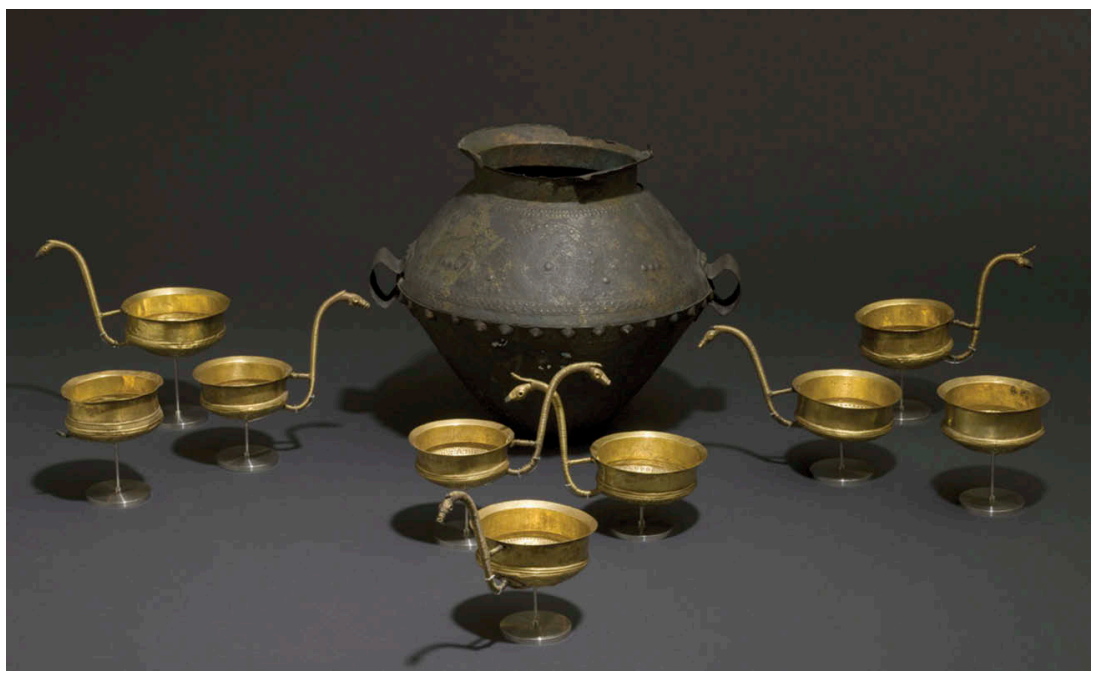

Figure 6. Late NBA bronze amphora adorned with sun-bird-ship motif and originally containing the 11 gold bowls adorned with solar symbols and handle composed of a swan's neck terminating in the head of a bull-horned horse. Connection with transitory solar rites and drinking rituals to support social cohesion in the warrior fellowship might be suggested. Mariesminde Mose, Funen (Courtesy of the National Museum of Denmark, photo: Roberto Fortuna \& Kira Ursem). 


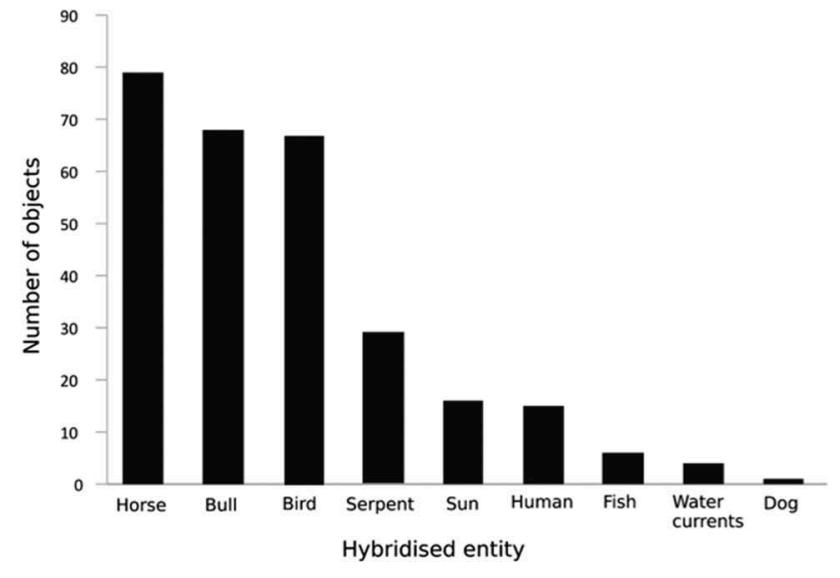

Figure 7. Frequency of different entities on 107 metal objects (83 razors, 9 figurines, 5 pieces of jewellery, 2 helmets/masks, 2 vases/amphoras, 2 shields, 1 comb, 1 tweezer, 1 spearhead, 1 drinking vessel) (Müller 1921, Brøndsted 1938, Broholm 1952, 1953, Kaul 1998a, 1998b, Sommerfeld 2010). Based on prior analysis in Ahlqvist 2016 (unpublished).

body, swan neck and head and, more anonymously, legs, tail and hair.

Some of these entities (animals, water currents, sun) and parts of them are more often hybridised than others. Horses, bulls and birds form part of the hybrid on the far majority of objects, whereas serpents, humans and suns are underrepresented (see Figure 7). It should, however, be noted that even though horse, bull and bird all appear on a large number of objects, these hybrids are mainly horse bodies or horse heads combined with beaks and horns, not bulls with horsetails etc. Additionally, the individual animal parts that feature most often are the components of beak and horns. Legs and oversized, round eyes are the second-most common parts (Figure 8). Hair, i.e. manes and beards, are much less common, but these parts may well have existed as real world additions that could be worn, which might be evident from the remains of bird's feathers in the small holes on either side of the crest on the helmets from Viksø (cf. Vandkilde 2013).

Some creatures look so strange and stylised that it cannot be clearly determined which animals or parts of animals they might represent. At times, it appears that one angle resembles one animal while a different angle resembles another. This is potentially an analytical problem; however, it may be

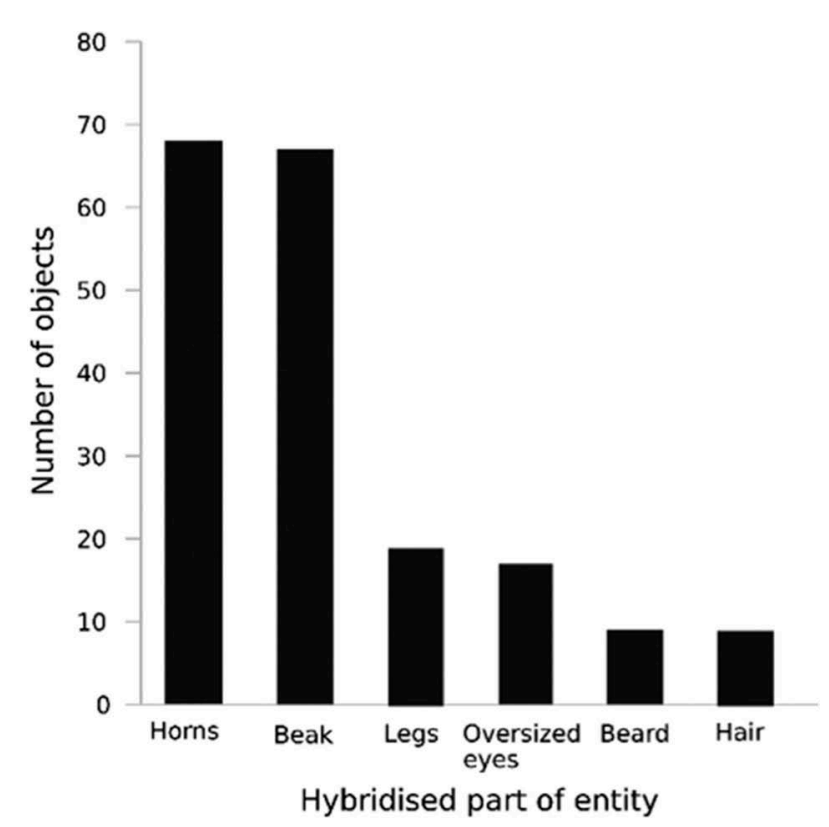

Figure 8. Frequency of the hybridised elements from different entities on 107 metal objects (83 razors, 9 figurines, 5 pieces of jewellery, 2 helmets/masks, 2 vases/amphoras, 2 shields, 1 comb, 1 tweezer, 1 spearhead, 1 drinking vessel) (Müller 1921, Brøndsted 1938, Broholm 1952, 1953, Kaul 1998a, 1998b, Sommerfeld 2010). Based on prior analysis in Ahlqvist 2016 (unpublished).

intentional and interpreted as evidence of fluidity between different animals and other beings.

Razors with images on the blade are by far the most common space for hybrid figuration involving both anthropomorphic and, particularly, zoomorphic iconography (Figure 9). The razor and its find contexts of burial or sacrifice in sacred places link variously with rites of passage, hence transformation from one stage of being to another. Shaving might even be seen as a rite of passage in itself (Leach 1958, p. 149ff). This said, razors are very particular objects in the NBA as they routinely combine with other tools used to groom the body of the beautiful warrior in the higher echelons of NBA society (Treherne 1995, Vandkilde 2017, 2018). This is similarly signified by the presence of hybrids on combs and some tweezers also belonging in the domain of male body grooming. The hybrid motifs on razors often signify different stages in the sun's travel between and across the spheres of cosmos (Kaul 1998a, 1998b). Hybrid creatures enable the journey while transforming when entering different realms of the cosmos. 


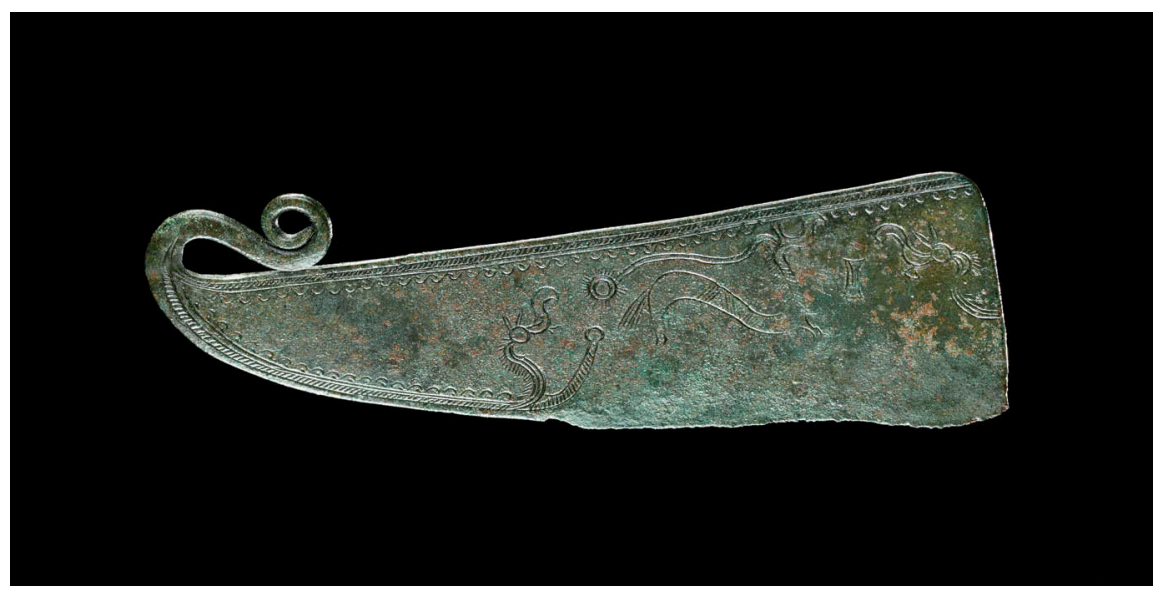

Figure 9. Late NBA razor with hybrid imagery on the blade. The creature, which appears on the prow and stern of a ship next to an apparent 'sun-horse' seems to be a combination of a horse with horns, a beak, an accentuated eye and a triangular beard (Courtesy of the National Museum of Denmark, photo: John Lee).

Hybrids on shields and the helmets from Viksø also broadly link with warfare and warriorhood (see above) but simultaneously with certain reiterated rituals associated with the solar myth or other central myths. Hybrids on bronze and gold drinking vessels are situated in a similar intersection in which the consumption of beverages may have served double purposes by maintaining certain cosmological myths as well as social cohesion among groups of high-ranking warriors. The golden bowls with solar symbols and handles terminating in bull-horned horse heads illustrate the exquisiteness of the endeavour (Figure 6). Figurines form another space in which hybridity is played out (Figure 2). Such bronze miniatures, not all distinctly hybrid, were probably attached to models of vehicles, in particular ships, as has been suggested for Grevensvænge and Fårdal (Glob 1962). The entire scenery was likely meant to evoke and circulate crucial mythical events among the people participating in the ritual.

In summary, interspecies hybridity on NBA metalwork follows a prescribed canon with preference for certain animals and combinations of these. The canon involves redundancy in terms of the select material media disseminating the hybrids. The preferred range of amalgamations and their contexts align well with the above ideas of bodily transformation in an animistic worldview and, overall, with the transmission of ritual knowledge among privileged peers (see Larsson 2002).

\section{The chronology of hybrid imagery}

The far majority of metal items with hybrids belong in the Late NBA c. 1100-500 BCE. However, the question of their beginning is not clear-cut, and hybrids seem to have existed in the Early NBA as well. One clue to this is the bull-horned device from Hagendrup in North Zealand made of gold plated bronze and, based on the spiral decoration, clearly dating to NBA II. It has been interpreted as a horse's mask (Kaul 1998a, p. 30, fig. 23) in anticipation of the later bull-horned horses known from the gold bowls and the Fårdal figurines (Figure 2,8). Still, it is uncertain whether Hagendrup should count as a hybrid or not (cf. Kaul 1998a, p. 29f, Kristiansen and Larsson 2005, p. 333).

The Kivik cist with the processions of bird-like humans (or human-like birds) on two of the carved slabs make a very plausible hybrid dating to early NBA II c. 1500-1400 BCE (Figure 9a). These strange human-animals have been compared to the Glasbacka celt (Figure 9d), often dated typologically to the final NBA and, recently by Goldhahn, categorised as a hybrid between bird and human (2013, p. 530f). In terms of the framework of the present study, this $7 \mathrm{~cm}$ long celt-like item (Figure 10a) combines the beak of a falcon (or other bird of prey) with a human face with one eye blind and the other seeing. The resemblance to Kivik is striking.

Bird-humans depicted on rock panels also sometimes appear very early. Not far from Kivik, on the Simrishamn panel, bird-faced males - apparently 

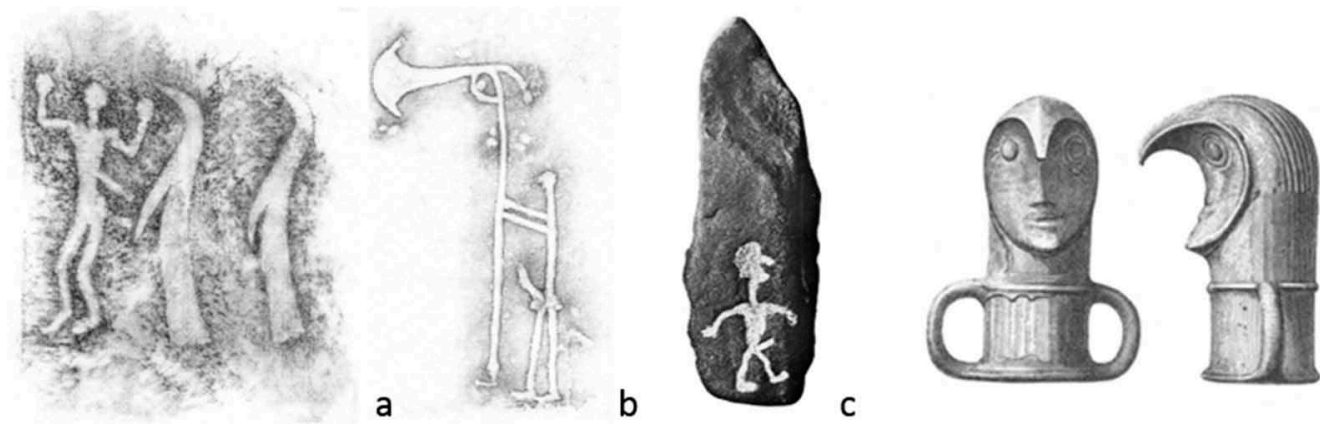

C

d

Figure 10. Early NBA bird-humans: a: Kivik cist (NBA II), b: Simris rock panel (NBA IA) on the coast of southeast Scania and c: a slab from Truehøjgård, Jutland, (NBA I-II) compared with d: NBA falcon-human from Glasbacka, Halland (NBA V?), which may have adorned the prow of a ship model. Shape, eyelets and socket suggest axe-like qualities on top of bird-human traits, also reminiscent of the imagery found at Viksø, Fogdarp and Grevensvænge. (a and b after Skoglund 2016, fig. 2.8, Evers Dietrich 1970: Source SHFA (www.shfa.se), fig. 2.1, Evers Dietrich 1970: Source SHFA (www.shfa.se), c after Glob 1969, fig. 18, d after Montelius 1922, fig. 1476 a, b).

warriors - wield huge axes (Skoglund 2016) (Figure 10b). The particular shape and size of the axes and the procession character of the Simrishamn scenery clearly match the oversized, flanged axes with half-circular cutting edge, deposited at the lengthy palisade of multiple posts at ArildshovBoest in central Jutland. Simrishamn and Arildskov both date to NBA IA 1700-1600 BCE, based on axe typology and $14^{\mathrm{c}}$ (cf. Vandkilde 1996, p. 97ff, 211ff, Rassmann 2015).

Dating on the basis of rock art may be deemed problematic (Brøndsted 1938, p. 12, Horn and Potter 2017). Recent advances in this respect are due to the quite detailed chronology of ships and comparisons with bronze object typology (Kaul 2004, Ling 2008, Skoglund 2016). NBA II and NBA $\mathrm{V}$ are floruit periods regarding imagery on both bronze and rock, and it would seem strange if especially the prominent bird-humans on Kivik and Simrishamn did not have counterparts in contemporaneous rock art.

In summary, a practice of hybridisation emerged immediately prior to the breakthrough of the NBA and probably developed further during NBA II. However, the mature phenomenon of hybrids associates with Late NBA. Major sociocultural changes took form already during the transition 1300-1100 BCE, notably in burial practises where the flames of cremation offered full bodily fluidity and transformation, but also in material culture and depositional rituals (Fokkens 1997, p. 360ff, Kaul 2004, p. 232f, Kristiansen and Larsson 2005, p. 318, fig. 146), and it is interesting that the mature hybrid phenomenon co-occurs with these. Nevertheless, it is worth repeating that simple crossbreeds occurred throughout the NBA, like the ones found early on in the ship-formed scimitars (e.g. Vandkilde 2014), animal-headed devices (e.g. Figure 5) and animal-adorned ships on rocks. While change and transformation in social order and beliefs can be posited, it is also true that a quintessential cultural tradition characterised the entire epoch.

\section{What does the repetitive order of hybrids in metal mean?}

Analysis of NBA hybridising iconography revealed preference for particular hybrids appearing in metalwork. This systematisation may be interpreted as a belief that some animals and objects had a special meaning or status: there are several possibilities, which do not exclude one another, and which involve transformation one way or the other. The apparent preference for combinations of human and animal body parts likely suggests that bodies and identities were generally perceived as fluid and unstable in the NBA. The hybrids are generally highly varied, though with some exceptions (see below), perhaps indicating that any being, human, animal or object could transform into another and back again. Thus, the hybrids most often co-appear with different hybrids on the same objects, and only relatively rarely are hybrids depicted with non-hybrids. Such liberal views on body and identity as well as of the boundaries between animals and humans are 
very much in line with key perceptions in various societies with animistic notions (Ingold 2011, p. 113f). In addition, some of the objects discussed here bear close resemblance to shamanic equipment, i.e. the Viksø helmets and perhaps even the Hagendrup find, which would mean that we can identify the shaman, another central feature in animistic communities (see Price 2002), in NBA society as well.

Hybrids may well connect to rituals (cf. Kaul $1998 \mathrm{a}$, p. 20ff, 2004, p. 342f), which would entail that some animals and objects had ritual significance alongside a greater social importance. This is underpinned by the fact that the vast majority of animal hybrids on bronzes are found on razors from urn burials, an inherently ritualised context (Bradley 2006, p. 375) in which bodily transformation is key. Death and the transition from one state of being to another is linked to rituals concerning the liminal phase in many societies, which, coupled with the 'monstrous images' on the razors, does suggest a ritual nature of the hybrids. However, these rituals do not necessarily have to be exclusively religious (i.e. tied to the belief system, cf. Garwood 2011, p. 261ff).

Additionally, the systematisation of the hybrid motifs could be viewed as evident of a universal cosmology of NBA myths and narratives - an association hard to reject in the light of much recent research by Kaul and others. By way of analogy, similar hybrid iconography on Iron Age objects has been interpreted as depicting Norse mythology as known from written sources (Figure 3). The key mythical and boundarycrossing role of the NBA horse highlights this because of its clear parallel in Norse mythology through the sky horses of Skinfaxi and Hrymfaxi and Odin's eight-legged horse Sleipnir, able to cross between worlds (cf. Hedeager 2011, p. 7f, p. 75). With the recognition of the hybrid phenomenon already in the Bronze Age we potentially see a continuous iconographic tradition of hybridising art in Scandinavia from the Bronze Age throughout the Iron and Viking ages and finally ending with the consolidation of Christianity in the thirteenth century (Hedeager 2011, p. 96ff, cf. Andrén 2014, p. 117ff). Perhaps this could be indicative of a continuous animistic tradition that terminated with the full adoption of a Christian worldview? This is an intriguing thought that would be worth pursuing in the future.

In augmentation of the above, we can identify the outline of a particular narrative or myth in Bronze Age imagery in the most common hybrid. This creature has a horse's head, bull horns, a beak, a triangular beard and oversized round eyes (see Figure 9). This composite being is almost always placed on the prow of a ship and in slightly different versions of the same posture, i.e. the chest is pushed forward, and the head tilted back, its nose pointing slightly upwards. The creature even features in relation to other non-hybrid animals, thus solidifying the idea that it is something more than merely a horse's head on a ship's prow (Figure 4). Furthermore, the creature is so widespread, both temporally and regionally, that it is very likely to have had large-scale interlinking importance. There are other examples of repetition in the hybridisations, albeit none were present on as many objects as the horned-beaked creature described above. Birds with horse manes and hooked beaks connected to the prows of ships, and humans with horns were also present on several objects.

In further support of a cosmological communality or identity, the same oversized round eyes feature in other hybridisations, although the aforementioned creature seems to be the only example of such a widespread, repeated combination of strictly selected traits. Notably, the oversized round eyes occur on bronze figurines such as the ones from Fogdarp (Kaul 1998a, p. 28, fig. 21) and Fårdal (Broholm 1953, p. 42f) and on the famed Viksø helmets (Broholm 1953, p. 24, Vandkilde 2013 , p. $167 \mathrm{ff}$ ). Given that this attribute seems to be a signifier of hybrids, it could be suggested that a creature with oversized round eyes perhaps should be considered a hybrid even if no other obvious hybrid features are present. Only one such object is known, i.e. the bronze figurine from Fårdal depicting a kneeling woman (e.g. Broholm 1953, fig. 317) (see Figure 2).

Fabulous animals such as the hybrids are, however, not necessarily linked solely to religion and cosmology - hence recognising that religion may intersect with other social issues and is ethnographically seen as deeply embedded in everyday 
practices in, for example, animistic societies. For example Julius Caesar's mentioning of monsters roaming the Gallic areas may have been warrelated political rhetoric to justify Roman expansion policy (Caesar 1869). Above, we have seen how hybridity and animal art in the NBA connected to the gear of war and the grooming of the bodies of high-ranking warriors, even if undoubtedly also carrying mythical and religious connotations. Bird-faced and bull-horned warriors of the NBA, usually shown with swords or other weapons, recall the animal warriors of the Norse Late Iron Age who signified the quality of being able to transform during war into eagle, boar or wolf, as the most prominent forms (cf. Hedeager 2011). Especially in the Late NBA, the bull-horned humans seem significant. Not only do they appear on one razor (Kaul 1998b, p. 86f, fig. 210), bronze figurines (Kaul 1998a, p. 28, fig. 21, Broholm 1953, p. 24, fig. 105, fig. 105a) and on the bronze helmets from Viksø (Vandkilde 2013), they are also a common motif in rock art (Kristiansen and Larsson 2005, p. 333). This repetition suggests that horned humans played an important role in Bronze Age iconography and cosmology, while it also implies that horned creatures may have been of overriding significance. A key example is the curious bronze figurine from Maribo, which even has three horns (Müller 1921, p. 52, fig. 185). This prevalence of horned humans further supports that the horns on horses are in fact horns and not just ears.

In summary, the systematisation of hybrids on/ in bronze points in the direction of a complex world of transformations in several intersecting domains of NBA society, while contributing immensely to a paramount cosmology of NBA mythical narratives, likely with commemorative and possibly socially unifying effects. The level on which this worked is not entirely clear albeit there is a link to the upper social ranks and perhaps especially males.

\section{Hybrids on rock and other media}

The hybrid creatures on bronze often find matches or deviations on rock art panels. Some degree of thematic congruence between rock and metal is generally recognised, as some similarities are too conspicuous to be mere coincidence: the horned or beaked humans, already discussed above, appear frequently on rock panels (Kristiansen and Larsson 2005, p. 333f) as well as on a single razor (Kaul 1998b, p. 86, fig. 210). These animal-humans also inhabit several other bronzes, such as the Viksø helmets (Vandkilde 2013), the Grevensvænge figurines (Broholm 1953, p. 24, fig. 105, fig. 105a) and the Fogdarp yokes (Kaul 1998a, p. 28, fig. 21).

Nevertheless, there are also clear discrepancies between the depictions in rock art and metal objects. Human-like figures are notably much more frequently carved in rock (Brøndsted 1938, p. 10 , Bradley 2006, p. $375 \mathrm{ff}$ ), especially the above somewhat stereotypic animal-humans. In addition, some of the same animals occur on rock, but not as hybrids and not in relation to ships. Rock art animals may have horns while other hybrid characteristics such as oversized round eyes seem absent.

The sun, commonly cross-breeding with other features on bronze items, is frequently shown in full and in companionship with humans on rock panels (Kjellén 1976, p. 125, p. 137, Kaul 2004, p. $345 \mathrm{ff})$. The sun is also often placed in different positions than on the razors, for example between the horns of an ox/bull, hovering above groups of animals, etc. (Kjellén 1976, p. 129). Besides, hybrids on rock feature other hybridisations than metalwork. For example, men with bird's wings and beaks as well as a man with two bird's heads are known from Kallsängen in Bohuslän (Aldhouse-Green \& Aldhouse-Green 2005, p. 95), and on a rock carving from Hällby in Litslena a man appears with a tree for a head (Kjellén 1976, p. 172). Such hybrid figures lack parallels on the bronze objects. The human/tree combination sometimes appears on clay pots, e.g. one from Haderslev (Broholm 1953, p. 269). However, on a similar pot from Føvling (Müller 1921, p. 34f) in Jutland, tree-like hands translate much better as humans with oversized hands, as the hand motif is frequent on rock and also occurs on the backside of Late NBA 'eyeglass' fibulae and on the Sandagergård cult house (Kaul 1985). Four-legged birds, also counting as hybrids, are engraved on the aforementioned clay pot from Føvling: this recalls another NBA bird-shaped urn with four 
legs (Broholm 1953, p. 50). More broadly, the fascination with waterfowl in the later NBA likely connects to ideas and beliefs circulating within a wider Bronze Age world, cremation practices and hence bodily transformation.

In summary, most Bronze Age hybrids adorn bronze razors and rock panels, respectively. Whilst razor hybrids mainly comprise a few selected animals and their parts (horse, bull, bird, snake), rock art shows a wider range of animal species and the hybrids are often humans combined with other animals and even plants (for example bull/ human, bird/human and human/tree). The disparity is surely rooted in the different possibilities offered by each of these media, such as obviously the large spaces of rock. As emphasised by Kaul (1998a, 2004), rock art and bronzes represent partly different properties of the same cosmology. Following this line of thought, hybrids on bronze often appear as 'snapshots' of particularly significant mythical scenes or condensations of these into symbols. By comparison, rock art motifs with hybrids are in some cases quite actionoriented, showing shamanistic solar rituals of transformation, while in other cases they depict excerpts from adventurous narratives implicating bird-warriors or bull-warriors on board or near longships.

\section{Conclusions}

This article has highlighted hybridisation in NBA imagery with the aim of clarifying this phenomenon, its background and role. NBA material culture is rich in simple crossbreeds such as between sword/ship and horse/ship occurring throughout the era, but full hybrids articulate compositions of body parts from two or more animals, including humans, and entangle with particular objects or images. Repeated combinations of animals notably comprise horse, bird, bull, snake and human. The rendering of hybrids follows a certain syntax, and the beasts occur with other images on metalwork and on rock as the primary media, but also sometimes show on funerary urns of clay. In terms of metalwork, hybrids occur especially on bronze razors but also on shields, helmets, bowls and combs, and in the shape of figurines: materials, forms and contexts suggest sacred rituals among an upper social rung with some particular reference to male warriors. Interspecies creatures occur ordered within each medium but also synchronised across media, and moreover cover a wide Southern Scandinavian geography. This may suggest that the phenomenon was socially and culturally embedded and, at least to some extent, shared. A strong presence of mythical narratives, and even an epic cycle pertaining to a gallery of celebrities, transpire (cf. Jensen 1990, Kristiansen and Larsson 2005, Vandkilde 2013).

Albeit appearing immediately prior to the breakthrough of the NBA c. $1700 \mathrm{BCE}$, the phenomenon of hybrids especially associates with the Late NBA, which saw somewhat opposing developments towards strong communality but also marked hierarchy. The belief system - perhaps mostly a way of perceiving, and enabling connectivity between, realms of the cosmos - seems geared to support both these trends. The numerous cremations testify to common beliefs in metamorphosis of the human body, and this aligns with the nexus of ethnographic and early historical analogues cited above. Interspecies composites, as manifested in the often socially elevated setting of NBA imagery, correspond equally well with ideas of bodily fluidity and transformation, in terms of critical transitions, or journeys, between the realms of the cosmos in some sort of eternal cycle (cf. Holst and Rasmussen 2015). The hybrids and their setting of social exclusivity may reveal a perceived ability to control such critical transitions through elaborate shape-shifting rituals. Social power is otherwise present in the clear link to warriorhood among an elite group.

References to warriorhood in relation to the inbetween imagery are, as mentioned, evident as they are especially prevalent on razors, shields, helmets and drinking vessels, and recall later accounts of warriors transforming into wolves, eagles and bears (Hedeager 2010, 2011). This resonates well with the ubiquitous possibility of transformation within animistic worldviews. Beaked and horned warriors are also displayed in rock art, thus indicating coherence between these and the hybrids in metal. Clear differences in hybridisation on rock art and metals are also present; however, bull-horned humans, appear in both media, and must have been of special importance. 
The interspecies hybrids stemming from burials, votive offerings and rock panels overall point to a ritually significant transformative iconography active in NBA religious practices and beliefs. Thus, the hybridised miniature figurines as well as the therianthropes and other apparent shamanistic solar rituals depicted on rock panels indicate that certain animistic traits were incorporated within NBA cosmology. However, NBA hybridising imagery does not indicate that the religion of the era is reducible to mere animism throughout, but that society certainly retained and put to use properties of an animistic tradition.

In summary and conclusion, the figuration and context of hybrids reveal properties of animistic beliefs in the NBA, probably intertwined with the strategies of an upper social rung among whom warriors, through their bodies and doings, were rendered prominent. The imagery of hybrids covers the NBA as a culture-geographical zone. This may suggest that the notion of shape-shifting, and the perceived transition between states of being, were also widespread. Furthermore, this belief, or aspects of it, served to mythologise and legitimise ambitions, leadership and privilege among certain social groups who clearly networked with one another.

\section{Acknowledgements}

We would like to thank Mathias Bjørnevad and William Frost for comments on early versions of the text and for English revision. We also wish to thank the anonymous reviewers for useful comments and valuable suggestions which have greatly contributed to the finalised version of the current article.

\section{Disclosure statement}

No potential conflict of interest was reported by the authors.

\section{ORCID}

Helle Vandkilde (D) http://orcid.org/0000-0001-9326-7633

\section{References}

Ahlqvist, L., 2016. 'Et Morkeligt Misfoster. Hybridvoesener på bronzer og helleristninger $i$ Nordisk Bronzealder. Dissertation (Bachelor). Aarhus University.
Aldhouse-Green, M. and Aldhouse-Green, S., 2005. The quest for the shaman. Shape-shifters, sorcerers and spirithealers of Ancient Europe. London: Thames \& Hudson Ltd.

Andrén, A., 2014. Tracing old norse cosmology. The world tree, middle earth, and the sun from archaeological perspectives. Lund: Nordic Academic Press.

Aner, E. and Kersten, K., 1973. Die funde der älteren bronzezeit des nordischen kreises in Danemark, Schleswig-Holstein und Niedersachsen, Band I, Frederiksborg und Københavns Amt. Copenhagen: PNM, Publications from the National Museum and Neumünster: Karl Wachholtz.

Arbman, H., 1980. Båtgravarna i vendel. Statens Historiska Museum, ed. Vendeltid. Stockholm: Statens Historiska Museum, 19-30.

Bradley, R., 2006. Danish razors and swedish rocks: cosmology and the bronze age landscape. Antiquity, 80 (308), 372-389. doi:10.1017/S0003598X00093698

Broholm, H.C., 1952. Danske oldsager III - Aldre bronzealder. Copenhagen: Gyldendalske Boghandel Nordisk Forlag.

Broholm, H.C., 1953. Danske oldsager IV - yngre bronzealder. Copenhagen: Gyldendalske Boghandel Nordisk Forlag.

Brøndsted, J., 1938. Bronzealderens soldyrkelse. Copenhagen: Gyldendalske Boghandel Nordisk Forlag.

Caesar, C.J., 1869. Caesar's gallic war. Oversattelse. New York: Harper and Brothers. W.A. McDevitte \& W.S. Bohn.

Conneller, C., 2004. Becoming deer. Corporeal transformations at star carr. Archaeological Dialogues, 11 (1), 37-56. doi:10.1017/S1380203804001357

Felding, L., 2015. Rock with a view: new perspectives on Danish rock art. In: P. Skoglund, J. Ling, and U. Bertilsson, eds. Picturing the bronze age. Oxford: Oxbow Books, 65-78.

Fokkens, H., 1997. The genesis of urnfields: economic crises or ideological change? Antiquity, 71 (272), 360-373. doi:10.1017/S0003598X00084970

Garwood, P., 2011. Rites of passage. In: T. Insoll, ed. The oxford handbook of the archaeology of ritual and religion. New York: Oxford University Press, 261-284.

Glob, P.V., 1962. Kultbåde fra danmarks bronzealder. Kuml, 1961, 9-18.

Glob, P.V., 1969. Helleristninger i Danmark. Odense og København: Jysk Arkæologisk Selskabs skrifter VII.

Goldhahn, J., 2005. Från sagaholm till bredarör hällbildsstudier 2000-2004. Gotarc Serie C. Arkeologiska skrifter No 62. Göteborg: Göteborgs Universitet.

Goldhahn, J., 2013. Bredarör på Kivik - en arkeologisk odyssé. Kalmar: Artes Liberales AB.

Hedeager, L., 2010. Split bodies in the late iron age/viking age of scandinavia. In: K. Rebay-Salisbury, M.L.S. Sørensen, and J. Hughes, eds. Body parts and bodies whole. Oxford and Oakville: Oxbow Books, 111-118.

Hedeager, L., 2011. Iron age myth and materiality; an archaeology of scandinavia AD 400-1000. London \& New York: Routledge. 
Holmqvist, W., 1951. Dryckeshornen från söderby karl. Fornvännen, 46, 33-65.

Holst, M.K. and Rasmussen, M., eds., 2015. Skelhøj and the bronze age barrows of southern scandinavia. Vol. 2. Aarhus: Jutland Archaeological Society.

Horn, C. and Potter, R., 2017. Transforming the rocks - time and rock art in Bohuslän, Sweden. European Journal of Archaeology, 21 (3), 1-24.

Hultkrantz, A., 1978. Introduction: ecological and phenomenological aspects of shamanism. In: L. Bäckman and $\AA$. Hultkrantz, eds. Studies in lapp shamanism. Stockholm: Almqvist \& Wiksell International Stockholm, 9-35.

Ingold, T., 2011. The perception of the environment. essays in Livelihood, Dwelling and Skill. London \& New York: Routledge.

Insoll, T., 2011. Animism and Totemism. In: T. Insoll, ed. The oxford handbook of the archaeology of ritual and religion. New York: Oxford University Press, 1004-1016.

Jensen, J., 1990. The twin god with the axe. In: O. Olsen, ed. Oldtidens ansigt - faces of the past. Til hendes majestot dronning margrethe II 16. april 1990. Copenhagen \& Aarhus: Det kongelige Nordiske Oldskriftselskab \& Jysk Arkæologisk Selskab, 66-67.

Jordan, P., 2003. Material culture and sacred landscape: the anthropology of the siberian khanty. Oxford: Altamira Press.

Kaul, F., 1985. Sandagergård. fund af et kulthus med bautasten og helleristningssten med hænder som motiv, ferslev Sogn, Hornsherred. Acta Archaeologica, 56, 31-54.

Kaul, F., 1998a. Ships on bronzes. A study in Bronze Age Religion. Text. Vols. 3,1, Copenhagen: PNM, Publications from the National Museum.

Kaul, F., 1998b. Ships on bronzes. A study in Bronze age religion. Catalogue. Vols. 3,2, Copenhagen: PNM, Publications from the National Museum.

Kaul, F., 2004. Bronzealderens religion. Studier af den nordiske bronzealders ikonografi. Copenhagen: Det Kongelige Nordiske Oldskriftselskab.

Kjellén, E., 1976. Upplands hällristningar. The rock carvings of uppland, Sweden. Lund: Kungl. Vitterhets Historie och Antikvitets Akademien.

Kristiansen, K., 2016. Bronze age vikings? A comparative analysis of deep historical structures and their Dynamics. In: L. Melheim, Z.T. Glørstad, and H. Glørstad, eds. Comparative perspectives on past colonisation, maritime interaction and cultural integration. New directions in anthropological archaeology. Sheffield: Equinox, 177-186.

Kristiansen, K. and Larsson, T.B., 2005. The rise of bronze age society: travels, transmissions and transformations. Cambridge: Cambridge University Press.

Kristoffersen, S., 2010. Half beast-half man: hybrid figures in animal art. World Archaeology, 42 (2), 261-272. doi:10.1080/00438241003672906

Kveiborg, J., 2017. The Nordic Bronze Age Horse: Studies of human-horse relationships in a long-term perspective. Thesis (PhD). Aarhus University.

Larsson, T.B., 2002. De döda, de "andra" och djuren. In: J. Goldhahn, ed. Bilder av bronsålder - ett seminarium om förhistorisk kommunikation. Stockholm: Almqvist \& Wiksell International, 91-112.

Leach, E.R., 1958. Magical hair. The Journal of the Royal Anthropological Institute of Great Britain and Ireland, 88 (2), 147-164. doi:10.2307/2844249

Lindstrøm, T.C., 2012. "I am the walrus": animal Identities and merging with animals - exceptional experiences? Norwegian Archaeological Review, 45 (2), 151-176. doi:10.1080/00293652.2012.703687

Ling, J., 2008. Elevated rock art. Towards a maritime understanding of bronze age rock art in Northern Bohuslän, Sweden. Gothenburg: Intellecta Solna Gothenburg University.

Little, A., et al., 2016. Technological analysis of the world's earliest shamanic costume: a multi-scalar, experimental study of a red deer headdress from the early holocene site of Star Carr, North Yorkshire, UK. PLoS One, 11 (14), 1-10. doi:10.1371/journal.pone.0152136

Mauss, M., 1990. The Gift: the form and reason for exchange in archaic societies. London \& New York: Routledge.

Montelius, O., 1922. Swedish antiquities I. The stone age and the bronze age. Stockholm: P.A. Norstedt \& Söners Förlag.

Müller, S., 1921. Bronzealderens Kunst $i$ Danmark. Copenhagen: C.A. Reitzels Boghandel, H.H. Thieles Bogtrykkeri.

Niekum, M., 2008. Ethnogenesis, iconography and sogdian Shamanism. In: E. V. Rtveladze, K. I. Tashbaeva, T. SH. Shirinov \& Y.Y. Yabukov, eds. Culture of nomadic peoples of Central Asia. Samarkand: IICAS, 155-163.

Peoples, H.C., Duda, P., and Marlowe, F.W., 2016. Huntergatherers and the origins of religion. Human Nature [Online], 27 (3), 261-282. [Accessed 04 July 2018]. doi:10.1007/s12110-016-9260-0

Price, N., ed., 2001. The archaeology of shamanism. London: Routledge.

Price, N., 2002. The viking way. Religion and war in late iron age scandinavia. Uppsala: Uppsala University.

Rassmann, C., 2015. Pragtøkserne fra arildskov. Et depotfund fra bronzealderen. Midtjyske fortollinger - museum midtjylland. 2015, 28-40.

SHFA, n.d. Svenskt hällristnings forskningsarkiv. Et nationellt Arkiv för dokumentation och forskning [online]. Available from: http://www.shfa.se/[Accessed 1 August 2018].

Skoglund, P., 2016. Rock art through time: scanian rock carvings in the bronze age and earliest iron age. Oxford: Oxbow Books.

Sommerfeld, C., 2010. Die kehrseite-anmerkungen zur rolle des mondes in der Ikonographie der Bronzezeit. In: H. Meller and F. Bertemes, eds. Der griff nach den sternen. internationales symposium in Halle (Saale) 16-21. Februar 2005. Tagungen des Landesmuseums für Vorgeschichte Halle. Halle (Saale): Landesamt für Denkmalpflege und Archäologie Sachsen-Anhalt, Landesmuseum für Vorgeschichte, 537-551.

Stringer, M.D., 1999. Rethinking Animism: thoughts from the infancy of our discipline. The Journal of the Royal Anthropological Institute, 5 (4), 541-555. doi:10.2307/2661147

Treherne, P., 1995. The warrior's beauty: the masculine body and self-identity in Bronze Age Europe. European 
Journal of Archaeology, 3 (1), 105-144. doi:10.1179/ 096576695800688269

Tylor, E., 1871. Primitive culture: researches into the development of mythology, philosophy, religion, art, and Custom. Vol. II, London: Bradbury, Evans and Co.

Vandkilde, H., 1996. From stone to bronze: the metalwork of the late neolithic and earliest bronze age in Denmark. Aarhus: Aarhus University Press. (Jutland Archaeological Society publications, 32).

Vandkilde, H., 2013. Bronze age voyaging and cosmologies in the making: the helmets from viksö revisited. In: S. Bergerbrant and S. Sabatini, eds. Counterpoint: essays in archaeology and heritage studies in honour of professor kristian kristiansen. Oxford: BAR International Series 2508, Archaeopress, 165-177.
Vandkilde, H., 2014. Breakthrough of the nordic bronze age. Transcultural warriorhood and a Carpathian crossroad in the $16^{\text {th }}$ century BCE. European Journal of Archaeology, 17 (4), 602-633. doi:10.1179/ 1461957114Y.0000000064

Vandkilde, H., 2017. The Metal hoard from pile, scania. place, things, time, metals, and worlds around 2000 BCE. Aarhus: Aarhus University Press.

Vandkilde, H., 2018. Body aesthetics, fraternity and warfare in the long European Bronze Age - postscriptum. In: C. Horn and K. Kristiansen, eds.. Warfare in bronze age society. Cambridge: Cambridge University Press, 229-243. Wylie, A. 1985. The reaction against analogy. In: M.B. Schiffer, ed. Advances in archaeological method and theory. New York: Academic Press, Vol. 8, 63-111. 